\title{
Library Cooperation in Metropolitan New York: Report of Work
} in Progress'

Mr. Gelfand is librarian, Queens College, 1 lushing, N.Y.

$\mathrm{T}$

HIs report on library cooperation in Metropolitan New York is limited to a description of the activities of a group of librarians who were brought together as a result of discussions of library cooperation initiated early in 1948 by Raymond B. Fosdick and Devereaux C. Josephs, then presidents, respectively, of the Rockefeller Foundation and the Carnegie Corporation of New York. It is a report of work in progress; no conclusions or recommendations can be presented at this time.

The foundations indicated their interest in the subject on Jan. 20, I948, at a dinner to which they had invited representatives of the governing boards of several institutions of higher education and of some libraries. The occasion was notable for an agreement that, for various reasons, among them the rapidly diminishing financial resources on which private libraries and educational institutions have depended, the possibilities of cooperation should be studied with a view toward helping the libraries of metropolitan New York to meet their service obligations at a minimum cost. It was further agreed that the representatives present would un-

1 Paper presented at the General Session, A.C.R.L., Chicago, January $28,1950$.

(Editor's Note: Attention is called to the paper by $\mathrm{Dr}$. Carl M. White, also included in this issue. Although the papers by Mr. Gelfand and Dr. White were prepared independently, readers will find that they supplement each other.) dertake to support such activity as might be found practicable. The foundations did not commit themselves to any particular action in this connection.

On Feb. I2, 1948, the foundations gave another dinner. On this occasion the guests were, in the main, the librarians from the institutions represented at the original dinner. The discussion of library cooperation was continued by the librarians who, as might be expected, agreed unanimously on the need for closer cooperation and discussed specific proposals for achieving this objective. Then there followed the activity that will be described here.

A group of 26 librarians, including those who had attended the dinner meeting but representing a larger number of different types of libraries was invited by Dr. Carl M. White on Feb. 24, I948, to discuss cooperation. The organization of this group was informal and remains so. In preparation for this meeting White asked each of I 2 librarians to come prepared to discuss a particular aspect of the subject. Most of these librarians, in turn, invited small groups of colleagues to join them in discussing their subjects.

The 12 topics presented at the February 24 meeting could be grouped into four large categories: (I) Resources, (2) Readers, (3) Technical services and operations, and (4) Physical problems.

Most of the reports presented at this 
meeting, although hastily prepared, represented in remarkable degree the major problems with which librarians are faced in the consideration of these four categories.

The first meeting of the larger group served to open wide the whole complex problem of cooperation and explored some of the possible approaches to the problem. The second meeting, which took place on March 12 was devoted to a discussion of the 12 reports presented at the previous meeting, and also to an analysis of the problem of library cooperation by Archibald MacLeish, as well as to finding what Carl White called "a handle" by which the committee could take hold and get under way.

MacLeish's analysis was, in a sense, a philosophical approach to a determination of the place and function of the library in our society. His remarks were applicable to library problems generally although they were directed specifically to the problems of library cooperation in New York. ${ }^{2}$ He said:

The real problem is . . not whether libraries ought to cooperate ... the problem is not whether cooperation is possible. ... The real problem is in what way to cooperate: to what end? Which raises the fundamental question which must be examined before a program of cooperation can be devised:

What is a library in our kind of world and what function does it exist to perform?

Considered in relation to the requirements of a society such as ours, it will become apparent that the library function is not the function of social memory alone-the mere preservation of records-but a much more active and creative function which can best be described by likening the library in a contemporary society to the nervous system in a physical organism-an instrument not of memory alone but of memory plus communication plus impulse to action plus reflection upon action.

2 The following quotations from MacLeish are taken from a letter which he wrote to Ralph $A$. Beals in which he restated the principal points that he presented at the March 12 meeting. MacLeish's letter appears as Appendix I to "Library Cooperation in Metroplitan New York; Report of a Second Meeting of New York City Librarians, March I 2, I 948 ." I I p. Mimeographed.
Considered in this relation it will be apparent, also, that libraries are not and cannot be independent and autonomous institutions however their directors and trustees and benefactors may wish to make them so. They are units in a system which is as extensive-or should be as extensive-as the society (and ideally of the civilization). They constitute together one system.

How well do libraries perform this function: how well do they function as the nervous system of a vast, complicated and closely integrated organism? Librarians generally will agree, even without a detailed survey, that the American library system, which is probably better than any other national system, performs this function in a spotty way. It is like a nervous system made up of trunk nerves to the right hand and the left toe. Not to push the physiological analogy too far, American technological society is comparable in some ways to the sabertooth and other huge animals which were superseded not because they lacked strength but, apparently, because their nervous systems were inadequate to their bulk. Librarians will probably agree also that the underlying trouble with the American library system is that it is not systematic.

Then MacLeish gave his approach to the solution of the question, "How do you systematize a system that is not systematic?" His principal contribution at this point, it seemed to me, was to be found in the first step of the approach that he suggested:

You begin by trying to reach agreement as to what the system has to do in the area under study. This is an inquiry at the highest levels of intellectual statesmanship. It is, however, a labor which librarians are peculiarly equipped to accomplish. They know, or can know, what the demands upon their system are and-more important and difficult-they can conceive what those demands ought to be if the system really worked. They also are competent to evaluate these demands qualitatively as well as quantitatively. My principal complaint about librarians in universities and public administrations is that they are too humble-too willing to be turned into superior janitors. They and they alone have the knowledge to plan and control the functioning of this most essential of social organs. 
They belong in the GHQs-the planning boards-of their universities and cities. The problem this committee is dealing with will never be solved intelligently and with technical competence until librarians demand that authority for themselves and exercise it.

It was finally agreed at the March I 2 meeting that the group would continue its investigation of the possibilities of cooperation. A small committee was appointed by Dr. White to "lay out concrete proposals for action." 3 This committee was composed of Ralph A. Beals, chairman, Ernest Hettich, and R. W. G. Vail.

No further action was taken until May 28, 1948, when the New York Library Club sponsored an open forum on library cooperation at its annual meeting. The club membership was provided with a brief summary of the preliminary discussions on cooperation through the medium of the New York Library Club Bulletin. ${ }^{4}$ Mr. Beals and his committee were invited to present their report at the forum.

The Beals committee stated that it was not in a position to present a final report but that it was prepared to discuss certain aspects of the problem of cooperation. The committee indicated that it was interested primarily in research libraries, "somewhat" in "working" or "reference" libraries and very little in "popular" libraries. It was pointed out that there are about 400 reference and research libraries in the metropoli$\tan$ area but that these libraries in no way constitute a system. The character of the clientele of reference and research libraries was discussed and their requirements and size received attention. Changing concepts concerning the functions of research libraries were noted.

Under the heading, "Cooperative activity that can be effected within the present

${ }^{3}$ White, Carl M. "Memorandum to the Librarians of New York Libraries." $2 \mathrm{p}$. Mimeographed.

4 New York Library Club. Bulletin, 36:16-17, May 1948. framework, with no new 'machinery' and at little or no expense," the Beals committee listed the following:

I. The elimination of duplication of littleused materials in a subject field coupled with the extension of the coverage in that field.

2. Division of fields with a view to coverage: i.e., a "little Farmington Plan."

3. Re-examination of the provision for particular groups or users of classes of publications.

4. Coordination and integration of present procedures.

5. Subject inventories.

Cooperation activity that requires new "machinery" and added expense, at least in initiating stages, included, according to this committee:

I. Provision of additional reference libraries.

2. Deposit libraries

a. "Passive": little-used materials.

b. "Active": "reserve" library for acquisition, cataloging and lending (to libraries) of new publications as they appear in categories like government documents of smaller states, non-Anglo-American law, publications of minor societies and academies, etc.

3. Cooperative buying and cataloging.

4. Union catalogs: general, special, finding lists.

5. Disposal of duplicates.

6. Binding.

7. Photographic reproduction. ${ }^{5}$

The Beals committee discussion took place verbally and informally but it served a most useful purpose by defining further the scope and character of library cooperation as viewed by the group originally formed to investigate that subject, and by

\footnotetext{
5 From a mimeographed outline prepared by the Beals committee for their use in the discussion on May 28 , I948.
} 
informing New York librarians at large about some of the difficult problems that arise in the consideration of cooperative activities.

There was no important activity during the summer months, a condition that will be familiar to most of us. In the fall members of the committee, faced with increasingly heavy burdens in connection with their regular responsibilities, were unable to devote any time to the project.

Although formal activity had come to a standstill the problems that had been uncovered and the need for cooperation persisted. In the fall of 1949 , therefore, Dr. White decided to make an attempt to resume the discussions and investigations relating to library cooperation. On October I 8 he invited five librarians-members of the original group-to join him in forming a steering committee, by way of continuing the leadership that had asserted itself previously and of sharing with him the responsibility for developing a practical program of cooperation.

The Steering Committee decided that its principal functions would be to:

I. Initiate proposals for library cooperation.

2. Form committees of personnel other than Steering Committee members to study and investigate these proposals.

3. Direct the conduct of any investigations undertaken by such committees by calling for preliminary outlines of the problems to be studied, progress reports and final reports.

4. Maintain close liaison with project committees by assigning Steering Committee members to serve as liaison officers on project committees when advisable. ${ }^{6}$

Membership of the Steering Committee, in addition to Dr. White, includes: Ralph A. Beals, director, New York Public Li-

\footnotetext{
6 "Minutes of the Steering Committee on Cooperation among Libraries of Metropolitan New York." r949-50. p.I.
}

brary; Sidney B. Hill, librarian, Association of the Bar of the City of New York; R. W. G. Vail, director, New York Historical Society ; Jerome K. Wilcox, librarian, The City College; and Morris A. Gelfand, librarian, Queens College, who was elected secretary.

The Steering Committee decided at its first meeting to adopt for investigation four subjects suggested by Wilcox, with the object of reaching a conclusive point in each before the end of May I950. These subjects were:

I. Division of subject fields.

2. A deposit library.

3. Messenger service.

4. Improvement of library service in colleges and universities.

It was agreed that this committee should not take upon itself the burden of active participation in and administration of projects initiated by it. The procedure would normally consist of recruiting competent personnel from outside the ranks of the committee to direct and serve on project committees, each organized to study a specific proposal. The Steering Committee would assure itself that the proposal was well outlined, the problem thoroughly understood, by the project committee. It would call for and discuss reports from project committees and consider appropriate action when final reports were received.

At subsequent meetings the Steering Committee defined the geographical area of cooperative activity, ${ }^{7}$ and reaffirmed its intention to aim at coordination of library facilities and services primarily to encourage their economical use for research and investigation.

By Dec. I 2, I949, four project com-

7 The definition of the New York-Northeastern New Jersey area, as supplied by the U.S. Bureau of the Census, was accepted subject to later modification should that proved desirable: New York City (Bronx, Kings, New York, Queens, and Richmond counties). Nassau, Rockland, Suffolk, and Westchester counties, New York; Bergen, Essex, Hudson, Middlesex, Passaic, Somerset and Union counties, New Jersey. 
mittees had been fully organized. John Fall, chief of acquisitions, New York Public Library, agreed to head a committee on the division of subject fields; John Berthel, Nicholas Murray Butler Librarian, at Columbia University, accepted the chairmanship of the committee on a storage library; Wayne Shirley, director of the Pratt Institute Library and dean of the library school there, and Donald Wasson, assistant librarian, Council on Foreign Relations, agreed to head the committee on improvement of library service and the committee on messenger service, respectively.

Preliminary reports of the Subject Fields Committee and the Storage Library Committee were considered concurrently. Each of these committees had asked for further instruction concerning its investigation. It was found that a fundamental subject, common to both these reports, was the question as to whether the Steering Committee wished to investigate the possibilities of a central cooperative library instead of limiting itself to consideration of a deposit library. The central cooperative library was envisioned as an organization that would fulfil not only the storage function of a deposit library but also additional service functions that would make possible a larger number of cooperative activities in the areas of acquisition, cataloging, photographic services, reference work, interlibrary loans, and related activities.

The Steering Committee agreed to authorize these project committees to investigate the possibilities of a central cooperative library and agreed further that the following division of duties would be recommended to the project committees :

I. Questions relating to management and organization would be investigated by the Berthel committee.
2. Contents and program would be considered by the Fall committee. ${ }^{8}$

There is nothing more to report at this time except that the four project committees are at work and it is hoped that their final reports will be completed this spring. If the time schedule is met, the Steering Committee hopes to be in a position to give careful consideration to the proposals of the project committees and to move ahead to a final decision by the end of May 1950 .

I cannot speak for the Steering Committee with respect to the possible outcomes of the investigations now sponsored by it but I would offer a personal opinion. I believe a good working approach to the problems of cooperation is being developed. At the very least, I should expect that we shall learn more about the resources and services of our neighbors, more about the clientele we serve. We shall have added to our experience in studying the organization of cooperative projects, and we shall probably discover personnel who have demonstrated a high capacity for investigating library problems.

The problems involved in the organization of a large scale cooperative project; fiscal, legal, psychological and others, are so complex that I would not offer an opinion at this time as to the possibility of organizing, let us say, a central cooperative library in the near future. But I believe that such a library or similar cooperative agencies inevitably will be organized in the New York area. The libraries of New York and for that matter those in the rest of the country cannot operate indefinitely without controlling their growth, coordinating their activities and re-examining their capacity to perform their basic functions. p. 6 .

8 "Minutes of the Steering Committee. . . "I949-50. 